\title{
USDA Hopes to Continue Current Information Collection Practices; NIH Finalizes Data Sharing Rules
}

\section{APHIS Asks for Extension of Approval for Information Collection}

On 14 March, in accordance with the Paperwork Reduction Act of 1995 (ref. 1), the United States Department of Agriculture (USDA) announced the intention of the Animal and Plant Health Inspection Service (APHIS) to "request an extension of approval of an information collection in support of the regulations issued under the Animal Welfare Act [AWA] governing the humane handling, care, treatment, and transportation of certain animals by dealers, research institutions, exhibitors, carriers, and intermediate handlers 2 ."

Research facilities must maintain records for animals covered under the AWA that are used for teaching, testing, and experimentation. APHIS uses this information to enforce the AWA and prepare annual Animal Welfare Enforcement reports to Congress. APHIS is asking the Office of Management and Budget (OMB) to approve its use of these information collection activities for an additional three years.

\section{NIH Announces Final Statement on Sharing Research Data}

On 26 February, the National Institutes of Health (NIH) announced that after 1 October, researchers submitting NIH grant proposals for $\$ 500,000$ or more in direct costs in a given year must include a plan for the "timely release and sharing of final research data from NIHsupported studies for use by other researchers ${ }^{3 "}$, or state why they cannot do

\begin{abstract}
Regulation Updates
Supreme Court Agrees with Abortion Foes

On 26 February, the Supreme Court of the United States ruled 8-1 that federal racketeering and extortion laws were wrongly used to try to stop blockades, harassment and violent protests outside abortion clinics. This is an important decision for anti-abortion activists that may encourage animal rights activists to use similar disruptive tactics against animal research facilities. Chief Justice Rehnquist delivered the opinion of the Court stating that the "petitioners did not commit extortion because they did not 'obtain' property from respondents as required by the Hobbs Act. We further hold that our determination with respect to extortion under the Hobbs Act renders insufficient the other bases or predicate acts of racketeering supporting the jury's conclusion that petitioners violated RICO [Racketeer Influenced and Corrupt Organizations Act] ".
\end{abstract}

USDA to Regulate Hunting, Breeding, and Security Dog Wholesalers

Effective 14 April, the USDA Animal and Plant Health Inspection Service amended the Animal Welfare Act regulations to clarify the fact that USDA regulates wholesale, but not retail, dealers of hunting, breeding, and security dogs. This amendment "makes the regulations consistent with [USDA] policy and, therefore, clarifies licensing and inspection requirements... ${ }^{\prime \prime}$. This final rule is unlikely to affect the use or availability of dogs for biomedical research.

so at least six weeks before the anticipated submission date of their research proposals. Individuals reviewing research proposals may not consider the proposed data-sharing plan when determining the scientific merit or priority score of the research proposal. Data must be made available when the main findings from the research set are accepted for publication. Additional information on data sharing is available in NIH's website ${ }^{4}$.

The "Privacy Rule" of the Health Insurance Portability and Accountability Act (HIPAA) is a federal regulation that governs how certain health care providers, health care clearinghouses, and health plans, use and disclose identifiable health information ${ }^{5}$. NIH requires investigators to protect the rights and privacy of people who participate in NIH-sponsored research at all times, and preclude information that would link to individual participants or identify them. The Office for Civil Rights (OCR) is the Departmental component responsible for implementing and enforcing the privacy regulation ${ }^{6}$.

\section{References}

1. Public Law 104-13. Paperwork Reduction Act of 1995. http://policyworks.gov/policydocs/16.pdf.

2. USDA APHIS. Notices. Notice of request for extension of approval of an information collection. Federal Register 68, 9632-9633 (28 February 2003).

3. $\mathrm{NIH}$. Final $\mathrm{NIH}$ statement on sharing research data. Notice: NOT-OD-03-032. $(26$ February 2003). http://grants.nih.gov/grants/guide/noticefiles/NOT-OD-03-032.html.

4. NIH. NIH Data Sharing Policy and Implementation Guidance website. http://grants.nih.gov/grants/policy/data_sharing/.

5. US DHHS. Office for Civil Rights-HIPAA Medical Privacy-National Standards to Protect the Privacy of Personal Health Information.

http://www.hhs.gov/ocr/hipaa/bkgrnd.html.

6. US DHHS. Office for Civil Rights Statement of Delegation of Authority. http://www.hhs.gov/ocr/fedreg.html.

7. Scheidler v. National Organization for Women, Inc. (01-1118). (26 February 2003). http://supct.law.cornell.edu/supct/html/01 1118.ZO.html.

8. USDA APHIS. Final rule. Licensing and inspection requirements for dealers of dogs intended for hunting, breeding, or security purposes. Federal Register 68 12283-12286 (14 March 14, 2003). 